\title{
СТАНДАРТИЗАЦІЯ ЯКОСТІ МЕДИЧНОЇ ДОПОМОГИ: ЕТАПНІСТЬ ЗАБЕЗПЕЧЕННЯ ЯКОСТІ НЕФРОЛОГІЧНОЇ ДОПОМОГИ ДИТЯЧОМУ НАСЕЛЕННЮ НА РЕГІОНАЛЬНОМУ РІВНІ
}

\author{
ВДНЗ «Буковинський державний медичний університет», м. Чернівці, Україна
}

\begin{abstract}
Мета: аналіз ефективності впровадження локальних клінічних протоколів надання медичної допомоги дитячому населенню з нефрологічними захворюваннями в Чернівецькій області.

Матеріали і методи. Матеріалом для даного дослідження була звітна документація про стан несрологічної допомоги дитячому населенню Чернівецької області за період 2013-2014рр. та дані Центру медичної статистики Міністерства охорони здоров'я України.

Результати. Проаналізовано ефективність роботи дитячої нефрологічної служби в Чернівецькій області після впровадження локальних протоколів надання медичної допомоги дітям з нефрологічними захворюваннями зниження показників поширеності і вперше виявленої захворюваності хвороб сечостатевої системи у дітей, які вперше за останні роки не перевищили загальнодержавні статистичні дані.

Висновки. Проведене дослідження дозволить здійснити аргументовані лікувально-реабілітаційні заходи на всіх етапах надання медичної (нефрологічної) допомоги дітям і розробити програми, спрямовані на поліпшення показників здоров'я та профрілактику цієї патології.
\end{abstract}

КЛЮчОВІ СЛОВА: локальний протокол медичної допомоги, якість медичної допомоги, нефрологічна патологія, діти.

Рівень якості медичної допомоги є одним 3 основних критеріїв її ефрективності [3;5;7]. Дієвим заходом щодо підвищення ефективності медичної допомоги населенню в Україні $є$ стандартизація якості надання медичних послуг (медичної допомоги) шляхом розробки та впровадження медикотехнологічних документів з доведеною ефективністю на галузевому та регіональному рівнях $[4 ; 6]$.

Відповідно до наказів МОЗ України, що регламентують основні напрямки підвищення якості та доступності медичних послуг [3;6], та наказів Департаменту охорони здоров'я та цивільного захисту населення Чернівецької обласної державної адміністрації (ДОЗ чОДА) «Про створення та впровадження медико-технологічних документів зі стандартизації медичної допомоги в Чернівецькій області» № 5 від 03.01.2013 р. та Управління охорони здоров'я Чернівецької міської ради «Про затвердження локальних протоколів медичної допомоги та клінічних маршрутів дітей з діагнозом «Гострий пієлонесррит», «Гострий гломерулонесрит», «Гострі кишкові інсрекції»» за № 48 від 13.03.2013 р., були розроблені та впроваджені в лікувальних закладах охорони здоров'я м. Чернівці, зокрема КМУ «Міська дитяча клінічна лікарня» м. Чернівці (спеціалізована нефрологічна допомога дитячому населенню в Чернівецькій області надається у нефрологічному відділенні лікарні, що виконує фрункції обласного відділення): «Локальний клінічний протокол медичної допомоги дітям 3 інсрекціями сечової системи» та «Локальний клінічний протокол

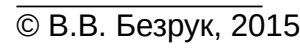

медичної допомоги дітям 3 гострим гломерулонесрритом», розробник - Т.П. Андрійчук - головний дитячий позаштатний нефролог ДОЗ чОДА, завідувач нефрологічного відділення КМУ «Міська дитяча клінічна лікарня» м. Чернівці; рецензент: В.В. Безрук - к.мед.н., доцент кафедри педіатрії, неонатології та перинатальної медицини Вищого державного навчального закладу України «Буковинський державний медичний університет», м. Чернівці.

Мета дослідження: проаналізувати результати та ефрективність впровадження локальних клінічних протоколів (ЛПМД) і клінічних маршрутів пацієнтів дитячого віку із нефррологічною патологією у лікувальних закладах охорони здоров'я Чернівецької області як першого етапу забезпечення стандартизації якості медичної допомоги на регіональному рівні.

Матеріали і методи. Вивчено офріційні статистичні дані щодо захворюваності та поширеності хвороб органів сечовиділення серед дитячого населення (звітна документація про стан нефррологічної допомоги дітям Чернівецької області за період з 2010 по 2014 рр. та дані Центру медичної статистики МОЗ України), при обробці використано інформаційно-аналітичний, статистичний методи.

Результати дослідження та їх обговорення. Аналізуючи роботу лікувальних закладів охорони здоров'я Чернівецької області з часу впровадження (2013-2014рр.) ЛПМД і клінічних маршрутів пацієнтів дитячого віку із несррологічною патологією, можна стверджувати про їх позитивний результат (табл.). Так, знизились показники поширеності і вперше виявленої захворюваності хворобами се- 
Таблиця. Показники захворюваності та поширеності хвороб органів сечовидільної системи серед дитячого населення Чернівецької області

\begin{tabular}{|c|c|c|c|c|c|c|c|c|c|c|c|c|c|c|}
\hline \multirow{4}{*}{$\begin{array}{l}\text { Адміністра- } \\
\text { тивно-тери- } \\
\text { торіальна } \\
\text { одиниця }\end{array}$} & \multicolumn{14}{|c|}{ Хвороби сечостатевої системи (на 1000 дитячого населення) } \\
\hline & \multicolumn{6}{|c|}{ поширеність } & \multicolumn{6}{|c|}{ захворюваність } & \multirow{2}{*}{\multicolumn{2}{|c|}{$\begin{array}{c}\text { на «Д» } \\
\text { обліку за } \\
2014 \text { р. }\end{array}$}} \\
\hline & \multicolumn{3}{|c|}{2013 p. } & \multicolumn{3}{|c|}{2014 p. } & \multicolumn{3}{|c|}{$2013 \mathrm{p}}$. & \multicolumn{3}{|c|}{$2014 \mathrm{p}}$. & & \\
\hline & $0-17$ & $0-14$ & $15-17^{*}$ & $0-17$ & $0-14$ & $15-17^{*}$ & $0-17$ & $0-14$ & $15-17^{*}$ & $0-17$ & $0-14$ & $15-17^{*}$ & $0-14$ & $0-17$ \\
\hline $\begin{array}{l}\text { Чернівецька } \\
\text { область }\end{array}$ & 57,8 & 46,47 & 1081,2 & 53,8 & 41,53 & 1108,3 & 28,1 & 22,7 & 522,5 & 22,9 & 17,95 & 457,5 & 23,36 & 29,7 \\
\hline Україна & 53,13 & - & - & 47,79 & - & - & 28,27 & - & - & 25,38 & - & - & - & - \\
\hline
\end{tabular}

Примітка: * - на 10000 дитячого населення.

чостатевої системи у дітей віком від 0 до 17-ти років і вперше за останні роки не перевищують загальнодержавні (захворюваність) $[2,9,10]$.

Позитивнізміни «стандартизації»наданнянефрологічної допомоги на регіональному рівні відповідно до загальнодержавних галузевих стандартів позначилися на вищезазначених показниках і у віддалених (територіально), а тому «проблемних» районах Чернівецької області. Так, у Сокирянському районі поширеність знизилась 3 61,2\% у 2013 р. до 50,83\% (2014р.), захворюваність - 3 35,0\% до 27,2\% відповідно; у Кельменецькому поширеність знизилася $387,4 \%$ до $61,8 \%$, захворюваність з 35,0\% до 23,3\%; у Путивльському районі поширеність знизилася з 68,2\% до 65,3\%, захворюваність - 3 31,9\% до 26,9\%.

Створені передумови щодо підвищення якості надання нефрологічної допомоги дитячому населенню у Чернівецькій області вимагають встановлення єдиних підходів для забезпечення принципів рівності і доступності на регіональному рівні. Подальші кроки у цьому напрямку повинні ґрунтуватися на циклі безперервного покращення та уніфікації впровадження в практичну діяльність медико-технологічних документів (рис.) [8].

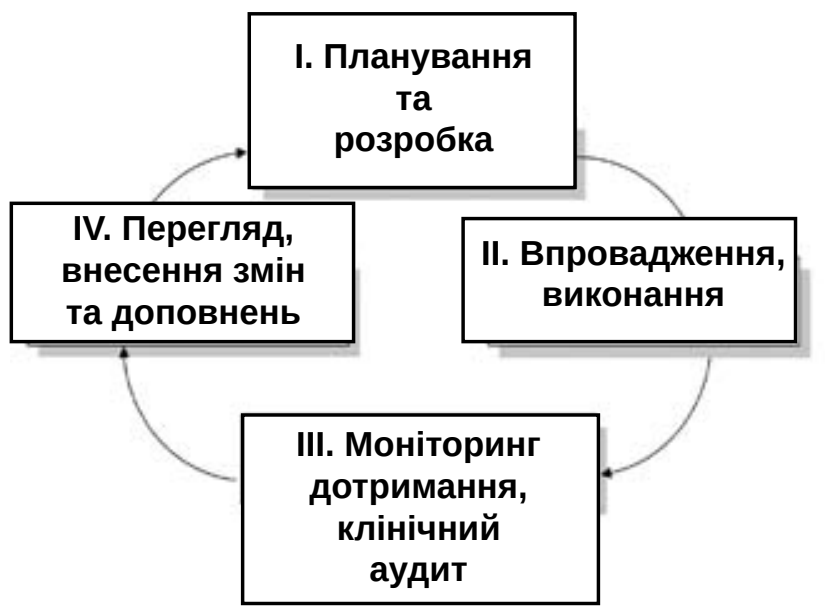

Puc. Безперервний цикл створення та подальшого удосконалення локальних клінічних протоколів медичної допомоги на регіональному рівні
Станом на 01.01.2014 р. територія Чернівецької області налічує 8,1 тис. кв. км (1,3\% території України), займаючи останнє місце за площею та третє за щільністю населення - на 1 км² припадає 112 жителів; до складу області входить 11 міст (з них два обласного підпорядкування - Чернівці та Новодністровськ, 9 - районного), 8 селищ міського типу та 398 сільських населених пунктів; частка регіону за чисельністю наявного населення загалом по Україні становить 1,94 відсотка; 904098 населення, у тому числі дорослого населення - 719369 осіб, дитяче населення - 184729 (діти - 150777 та підлітки - 33952) осіб; ґендерний розподіл всього населення області становить: жінки - 53,1\% від усього населення, чоловіки - 46,9\%; питома вага міського населення - 42,1\%, сільського - 57,9\% [1]. Враховуючи адміністративно-територіальні особливості Чернівецької області, вбачаємо доцільним, з метою підвищення якості медичної допомоги (на регіональному рівні), розробку та впровадження спільних узгоджених ЛПМД і клінічних маршрутів пацієнтів дитячого віку із нефрологічною патологією для лікувальних закладів охорони здоров'я I-III рівнів надання медичної допомоги.

\section{Висновки}

Впровадження локальних протоколів медичної допомоги та клінічних маршрутів пацієнта, що ґрунтуються на принципах доказової медицини, у практичну діяльність закладів охорони здоров'я на регіональному рівні є дієвим механізмом управління якістю, дозволяє забезпечити дотримання загальних принципів рівності і доступності медичної допомоги у державі.

Перспективи подальших досліджень. Розробка та впровадження у лікувальних закладах охорони здоров'я Чернівецької області спільних узгоджених локальних протоколів медичної допомоги дітям із нефрологічною патологією з метою уніфікації стандартів надання медичної допомоги на регіональному рівні; моніторинг, оцінка та науковий супровід варіанту розвитку моделі охорони здоров'я на регіональному рівні. 


\section{Список літератури}

1. Демографрічна ситуація Чернівецької області у 2013 році [Електронний ресурс] - Режим доступу : http://www. cv.ukrstat.gov.ua/publiy/nasel/dop/demsit_13.pdf. (27.11.15). - Назва з екрану.

2. Основні показники діяльності педіатричної служби в Чернівецькій області: статистично-аналітичний довідник, 2012-2014 рр. - Чернівці, 2015. - 353 с.

3. Про затвердження Концепції управління якістю медичної допомоги у галузі охорони здоров'я в Україні на період до 2020 року : наказ МОЗ України від 01.08.2011p. №454. [Електронний ресурс]. - Режим доступу : http:// mozdocs.kiev.ua/view.php?id=12655 (27.11.15). - Назва з екрану.

4. Про затвердження Методичних рекомендацій «Уніфікована методика розробки індикаторів якості медичної допомоги» : наказ МОЗ та АМН України від 11.03.2011 №141/21. [Електронний ресурс]. - Режим доступу : http:// search.ligazakon.ua/__doc2.nsf/link1/MOZ13158.html (27.11.15). - Назва з екрану.

5. Про затвердження Програми розвитку інвестиційної та інноваційної діяльності в Україні : постанова Кабінету Міністрів України від 02.02.2011p. № 389 [Електронний ресурс]. - Режим доступу : http:// zakon4.rada.gov.ua/ laws/show/389-2011-п (27.11.15). - Назва з екрану.

6. Про затвердження Уніфікованої методики з розробки клінічних настанов, медичних стандартів, уніфікованих клінічних протоколів медичної допомоги, локальних протоколів медичної допомоги (клінічних маршрутів пацієнтів) на засадах доказової медицини (частина перша): наказ МОЗ та АМН України № 102/18 від 19.02.2009 p. [Електронний ресурс]. - Режим доступу : http://www.moz.gov.ua/ua/portal/dn_20090219_102_html (27.11.15). Назва з екрану.

7. Про Національний план дій на 2012 рік щодо впровадження Програми економічних реформ на 2010-2014 роки «Заможне суспільство, конкурентоспроможна економіка, есрективна держава» : Указ Президента України від 12.03.2012 № 187/2012 [Електронний ресурс]. - Режим доступу : http://zakon4.rada.gov.ua/laws/show/187/2012 (27.11.15). - Назва з екрану.

8. Уніфрікована методика з розробки локальних протоколів медичної допомоги для закладів охорони здоров'я України : методичні рекомендації [Електронний ресурс] / А. В. Степаненко [та ін.]. - Київ, 2012 - 38 с. - Режим доступу : http://www.dec.gov.ua/mtd/doc/Met_LPMD.pdf. (27.11.15). - Назва з екрану.

9. Щорічна доповідь про стан здоров'я населення, санітарно-епідемічну ситуацію та результати діяльності системи охорони здоров'я України. 2013 рік / за ред. О. С. Мусія. - Київ, 2014. - 201 с. [Електронний ресурс] - Режим доступу : httр://www.uiph.kiev.ua/dawnload/Vidavnictvo/Shchorichna\%20dopovid/Щорічна\%20доповідь.2013.pdf. (27.11.15). - Назва з екрану.

10. Щорічна доповідь про стан здоров'я населення, санітарно-епідемічну ситуацію та результати діяльності системи охорони здоров'я України. 2014 рік / за ред. О. Квіташвілі; МОЗ України, ДУ «УІСД МОЗ України». - Київ, 2015. $-460 \mathrm{c}$.

\section{СТАНДАРТИЗАЦИЯ КАЧЕСТВА МЕДИЦИНСКОЙ ПОМОЩИ: ЭТАПНОСТЬ ОБЕСПЕЧЕНИЯ КАЧЕСТВА НЕФРОЛОГИЧЕСКОЙ ПОМОЩИ ДЕТСКОМУ НАСЕЛЕНИЮ НА РЕГИОНАЛЬНОМ УРОВНЕ}

В.В. Безрук

ВГУЗ «Буковинский государственный медицинский университет», г. Черновцы, Украина

Цель: анализ эффективности внедрения локальных клинических протоколов по оказанию медицинской помощи детскому населению с нефрологическими заболеваниями в Черновицкой области.

Материалы и методы. Материалом для данного исследования является отчетная документация о состоянии нефрологической помощи детскому населению Черновицкой области за период 2013-2014 гг. и данные Центра медицинской статистики Министерства здравоохранения Украины.

Результаты. Проанализирована эфрфективность работы детской нефрологической службы в Черновицкой области после внедрения локальных протоколов по оказанию медицинской помощи детям с нефрологическими заболеваниями - снижение показателей распространенности и впервые выявленной заболеваемости болезней мочеполовой системы у детей, которые впервые за последние годы не превысили общегосударственные статистические данные.

Выводы. Проведенное исследование позволит осуществить аргументированные лечебнореабилитационные мероприятия на всех этапах оказания медицинской (нефрологической) помощи детям и разработать программы, направленные на улучшение показателей здоровья и профилактику данной патологии.

КЛЮЧЕВЫЕ СЛОВА: локальнЫЙ протокол медицинской помощи, качество медицинской помощи, нефрологическая патология, дети. 
STANDARDIZATION OF QUALITY OF CARE:

STAGES ENSURE THE QUALITY OF NEPHROLOGY CARE FOR CHILDREN'S POPULATION AT THE REGIONAL LEVEL

V.V. Bezruk

Higher state education institution of Ukraine «Bukovinian State Medical University», Chernivtsi

Purpose: to analysis of the effectiveness of the implementation of local protocols Nephrology medical care to children in Chernivtsi region.

Materials and methods. The material for this study is reporting documentation about the condition of the nephrological service care for children's population of the Chernivtsi region in 2013-2014 and the data of The Center of medical statistics of Ministry of Health of Ukraine.

Results. To analyzed the effectiveness of pediatric Nephrology service in Chernivtsi region after the implementation of local protocols for providing medical care for children with nephrological diseases - reduction the prevalence and morbidity for the first time revealed diseases of the genitourinary system in children, which for the first time in recent years did not exceed national statistics.

Conclusions. The study will permit reasoned therapeutic and rehabilitation activities at all stages of rendering of medical (Nephrology) care for children and to develop programmes aimed at improving health outcomes and prevention of this disease.

KEY WORDS: the local Protocol of medical care, the quality of medical care, nephrology pathology, children's.

Рукопис надійшов до редакції 23.11.2015 p.

\section{Відомості про автора:}

Безрук Володимир Володимирович - к.мед.н., доцент кафедри педіатрії, неонатології та перинатальної медицини Вищого державного навчального закладу України «Буковинський державний медичний університет»; тел.: + 38(0372) 53-05-27. 